\author{
Elżbieta Biały \\ Instytut Nafty i Gazu - Państwowy Instytut Badawczy
}

\title{
Wykorzystanie enzymów do udrażniania strefy przyodwiertowej po dowiercaniu
}

\begin{abstract}
W artykule przedstawiono badania, których celem było sprawdzenie możliwości wykorzystania enzymów do usuwania uszkodzenia strefy przyodwiertowej spowodowanego przez składniki płuczki wiertniczej używanej przy dowiercaniu. Przedstawiono charakterystykę enzymów o potencjalnym zastosowaniu do usuwania osadów filtracyjnych oraz zaprezentowano przykładowe badania laboratoryjne nad wykorzystaniem enzymów do usuwania ,placka filtracyjnego" utworzonego przez płuczkę beziłową z blokatorami.

Słowa kluczowe: enzymy, placek filtracyjny, uszkodzenie strefy przyodwiertowej.

\section{The use of enzymes to restore patency to borehole zone after drilling}

The article presents research aimed at the possibility of using enzymes to remove the damage to the borehole zone caused by components of the drill-in fluid. The characterization of enzymes of potential use to remove sediment filter, as well as presenting examples of laboratory tests on the use of enzymes to remove the "filter cake" formed by the non-bentonite drilling mud is presented.
\end{abstract}

Key words: enzymes, filter cake, damage to the borehole zone.

\section{Wstęp}

Dowiercanie jest jedną z końcowych prac prowadzonych w otworze. Jest też czynnością, podczas której należy zachować ostrożność w doborze składników płuczki wiertniczej ze względu na możliwość wystąpienia szeregu zjawisk fizykochemicznych powodujących zmiany przepuszczalności skał zbiornikowych strefy przyodwiertowej. W krajowej praktyce wiertniczej do dowiercania złóż stosowane są najczęściej płuczki beziłowe [9, 10, 14], w skład których wchodzą następujące środki: inhibitory pęcznienia minerałów ilastych, blokatory, środki obniżające filtrację, zagęstniki i środki bakteriobójcze. Płuczkę taką stosuje się w celu ochrony strefy przyodwiertowej przed negatywnymi skutkami takimi jak: pogorszenie przepuszczalności skał złożowych czy wytworzenie osadu filtracyjnego na ścianie otworu, tzw. placka filtracyjnego (filter-cake). W przypadku wystąpienia uszkodzenia strefy przyodwiertowej przez placek filtracyjny do jego usuwania wykorzystuje się metody chemiczne, stosując następujące ciecze przemywające:
- kwasy,

- utleniacze,

- enzymy,

- kombinacje wyżej wymienionych środków.

W literaturze zagranicznej dotyczącej stymulacji można znaleźć przykłady eksperymentów i praktycznych zastosowań ostatniej z wymienionych metod [1, 6, 8]. Zazwyczaj polegały one na równoczesnym zastosowaniu w odwiercie różnych enzymów w kombinacji z kwasami [3]. Ich zadaniem było lepsze (dokładniejsze) oczyszczanie uszkodzenia strefy przyodwiertowej.

W Polsce wykorzystanie enzymów do usuwania uszkodzenia spowodowanego przez placek filtracyjny jest nowością. Najczęściej w tym celu wykonuje się kwasowanie. W prezentowanej pracy skoncentrowano się na enzymatycznej metodzie usuwania uszkodzenia spowodowanego przez płuczkę beziłową z blokatorami, zastosowaną do przewiercania interwału $1130 \div 2100 \mathrm{~m}$ w formacjach miocenu autochtonicznego, w kombinacji z metodą kwasowania matrycowego. 
Próba usuwania uszkodzenia z wykorzystaniem enzymów była wykonywana w Zakładzie Stymulacji Wydobycia Węglowodorów INiG - PIB po raz pierwszy. Dlatego też $\mathrm{w}$ trakcie jej realizacji, w miarę pojawiania się problemów, prowadzono dodatkowe badania laboratoryjne, których celem było lepsze zdiagnozowanie zachowania się enzymów w różnych warunkach temperaturowych, $\mathrm{pH}$ i przy różnej koncentracji substancji aktywnej. Rozszerzono plan badań także o badania interakcji roztworów enzymów z dodatkami chemicznymi stosowanymi do płynów zabiegowych. Sprawdzono również wzajemne interakcje pomiędzy enzymami do usuwania skrobi i celulozy. Wyniki tych badań mogą stanowić bazę do opracowania innych cieczy czyszczących na bazie enzymów.

\section{Charakterystyka składników płuczki wiertniczej powodujących tworzenie placka filtracyjnego}

Głównymi składnikami płuczki wiertniczej powodującymi uszkodzenie strefy przyodwiertowej przez placek filtracyjny są:

- zagęstniki,

- środki zmniejszające filtrację,

- blokatory, materiały obciążające.

Składniki te dodawane są do płuczki wiertniczej w celu nadania jej odpowiednich właściwości reologiczno-strukturalnych.

Zagęstniki używane są dla zwiększenia lepkości i wytrzymałości strukturalnej płuczki wiertniczej. Zalicza się do nich: biopolimery, żywicę guarową, hydroksyetylocelulozę (HEC) i niektóre polimery akrylowe. Najczęściej stosowanym zagęstnikiem płuczek wiertniczych są biopolimery. Jednym z nich jest żywica ksantanowa lub XC-polimer. Uznaje się go za polimer naturalny, chociaż otrzymywany jest w sposób sztuczny (zaliczana się go również do grupy polimerów modyfikowanych) [11].

Środkami zmniejszającymi filtrację są koloidy ochronne pochodzenia skrobiowego lub celulozowego. Działanie ich uwarunkowane jest zdolnością do uszczelnienia i zwiększenia wytrzymałości mechanicznej osadu filtracyjnego. Kolo- idem ochronnym jest skrobia, będąca polisacharydem o ogólnym wzorze chemicznym $\left(\mathrm{C}_{6} \mathrm{H}_{10} \mathrm{O}_{5}\right)_{\mathrm{n}}$, powstającym w wyniku fotosyntezy. W zależności od pochodzenia skrobia zawiera $10 \div 30 \%$ amylozy i $70 \div 90 \%$ amylopektyny. Celuloza, inaczej błonnik, jest wielkocząsteczkowym organicznym związkiem chemicznym z grupy wielocukrów (polisacharydów). Jedną z pochodnych celulozy stosowanych do regulowania filtracji i lepkości płuczek zasolonych jest polianionowa celuloza (PAC), nazywana również polianionowym polimerem celulozowym o dużej masie cząsteczkowej. Jej odporność temperaturowa określana jest na $150^{\circ} \mathrm{C}$, przy czym nie ulega ona rozkładowi biologicznemu [11].

Blokatory stosuje się w celu uniknięcia wnikania drobnoziarnistej fazy stałej, w tym ilastej, oraz filtratu w strefę chłonną [2]. Ich rolą jest szybkie wytworzenie osadu na ścianie otworu wiertniczego. Powstały osad powinien być lekko sczepiony ze skałą złożową, tak aby podczas wywoływania produkcji ciśnienie złożowe powodowało jego usunięcie, a ponadto $\mathrm{w}$ niektórych przypadkach mógłby być usunięty chemicznie (np. przez kwasowanie) [7]. Jako blokatory używane są różne odmiany węglanu wapnia $\mathrm{CaCO}_{3}$ (marmur, wapień, dolomit, kreda) oraz sole ziarniste (sól kamienna).

\section{Charakterystyka enzymów}

Enzymy są to wielkocząsteczkowe, w większości białkowe katalizatory, które przyśpieszają specyficzne reakcje chemiczne wskutek obniżenia ich energii aktywacji. Ze względu na proteinową naturę aktywność enzymów jest zależna od parametrów fizykochemicznych środowiska, tj.: temperatury i pH. Wpływ temperatury na aktywność enzymów nie jest prostą zależnością. Szybkość reakcji enzymatycznych wzrasta wraz z temperaturą, ale po przekroczeniu temperatury optymalnej postępuje denaturacja termiczna enzymów i ich aktywność gwałtownie spada. Większość enzymów ma optimum temperaturowe w zakresie $30 \div 45^{\circ} \mathrm{C}$ i nieodwracalnie denaturuje oraz traci aktywność w temperaturach wyższych niż $60^{\circ} \mathrm{C}$. Jednak w przypadku organizmów termofilnych (np. bakterii ze źródeł termalnych) ich enzymy zachowują aktywność i osiągają maksymalną szybkość w podwyższonych temperaturach.
Drugim ważnym parametrem środowiska charakteryzującym aktywność enzymów jest pH. Enzymy mają największą aktywność w swoim optymalnym zakresie pH i aktywność ta spada wraz ze zwiększeniem lub zmniejszeniem pH poza ten zakres. Szybkość reakcji enzymatycznych wzrasta również wraz ze zwiększaniem stężenia enzymu.

Enzymy są stosowane w przemyśle chemicznym, spożywczym i innych, głównie jako niezwykle specyficzne i bezpieczne w użyciu katalizatory. Ich wadą jest wrażliwość na skrajne warunki temperatury i pH, niestabilność w środowiskach innych niż wodne (np. rozpuszczalników organicznych) oraz stopniowa degradacja podczas użytkowania. Ograniczeniem ich uniwersalności jest także wysoka specyficzność. Obecnie enzymy produkowane są na skalę przemysłową głównie z zastosowaniem mikroorganizmów modyfikowanych genetycznie. 
W prezentowanej pracy enzymy zostały wykorzystane do usuwania uszkodzenia strefy przyodwiertowej. Ich działanie polega na zmniejszaniu lepkości placka filtracyjnego $[1,4$, 6-8, 12, 15]. Enzymami, które mogą być użyte do usuwania uszkodzenia spowodowanego przez płuczkę wiertniczą, są:

- amylazy - enzymy rozkładające amylozę i amylopektynę (składniki skrobi). Enzymy te zawierają dwa typy amylazy: alfa $(\alpha)$ i beta $(\beta)$, które w różny sposób powodują hydrolizę skrobi. A-amylaza jest z nich bardziej efektywna i degraduje polisacharydową skrobię na mniejsze jednostki oligosacharydowe: dekstryny i „zwykły” cukier [12]. Otrzymuje się ją w kontrolowanym procesie fermentacji z wykorzystaniem szczepu bakterii Bacillus licheniformis lub też w procesie biosyntezy z pomocą szczepu bakterii Bacillus subtilis [1];

- celulazy - enzymy rozkładające celulozę i jej pochodne. Są to endoglukanazy, egzoglukanazy i $\beta$-glukozydazy. Endoglukanazy (EG) katalizują losowo rozkład wewnętrznych wiązań łańcucha celulozy, egzoglukanazy $(\mathrm{CBH})$ atakują końce łańcucha, uwalniając cząsteczki celobiozy, a $\beta$-glukozydazy (BG) hydrolizują celobiozę do glukozy [5]. Degradacja celulozy jest utrudniona ze względu na występowanie wewnętrznych i zewnętrznych wiązań wodorowych, które stabilizują włókna celulozy. Proces hydrolizy celulozy składa się z następujących etapów: adsorpcji celulazy na powierzchni celulozy, degradacji celulozy do cukrów prostych oraz desorpcji celulazy z powierzchni materiału poddawanego hydrolizie;

- mannanazy - rozkładające polimery zbudowane z mannozy, np. guar - niszczą każde wiązanie $\alpha-1,2$ - albo $\beta-1,4-$ glikozydowe z podstawnikiem oraz wiązanie $\beta-1,4$ ze szkieletem biopolimeru [6, 7].

Enzymy te nie usuwają blokatora (np. węglanów) z placka filtracyjnego. Służą jedynie do usuwania zagęstnika (biopolimeru) i środka zmniejszającego filtrację (skrobi, pochodnych celulozowych). Do usunięcia blokatora wymagane jest wówczas wysokie ciśnienie złożowe, umożliwiające wyniesienie go na powierzchnię odwiertu. W przypadku niskich ciśnień konieczne jest zastosowanie dodatkowo kwasu w celu rozpuszczenia blokatora (np. węglanów).

\section{Badania laboratoryjne usuwania placka filtracyjnego z wykorzystaniem enzymów}

W celu wykonania badań laboratoryjnych odtworzono płuczkę wiertniczą, używając biopolimeru XCD, preparatów skrobiowych i celulozowych (CMC HV i CMC LV) i blokatorów węglanowych. Do usuwania uszkodzenia związanego z wytworzonym przez płuczkę wiertniczą plackiem filtracyjnym wykorzystano enzymy rozkładające skrobię oraz enzym rozkładający celulozę.

Do hydrolizy skrobi zastosowano:

- płynną $\alpha$-amylazę - enzym upłynniający - należy do amylaz dekstrynujących, rozrywających łańcuchy skrobi aż do wytworzenia maltozy. Wskutek działania $\alpha$-amylazy silnie spada lepkość produktów skrobiowych, gdyż $\alpha$-amylaza rozkłada skrobię na dekstryny o małych cząsteczkach, dając niewielką ilość maltozy. Temperaturowy zakres stosowania tego enzymu to $70 \div 100^{\circ} \mathrm{C}$, a optymalna temperatura: $80 \div 90^{\circ} \mathrm{C}$. Zakres pH: $5,2 \div 7,5$, optymalnie: $5,8 \div 6,8$. Przy stosowaniu preparatu w środowisku o $\mathrm{pH}$ odbiegającym od zalecanego zakresu należy zrobić korektę dawki enzymu lub skorygować $\mathrm{pH}$ środowiska działania enzymu przed dozowaniem preparatu;

- Tegamyl HL120L - stabilny preparat enzymatyczny zawierający $\alpha$-amylazę, otrzymywaną w kontrolowanym procesie fermentacji z wykorzystaniem szczepu bakterii Bacillus licheniformis. Jest on stosowany w celu szybkiego doprowadzenia żelowanej skrobi ziemniaczanej lub zbożowej do postaci ciekłej, o małej lepkości. W efekcie powstają rozpuszczalne w wodzie cząsteczki dekstryn, które ulegają hydrolizie. Optymalny zakres $\mathrm{pH}$ wynosi $5,8 \div 6,8$, a optymalny zakres temperatury: $80 \div 90^{\circ} \mathrm{C}$, ale enzym działa również efektywnie poza tym zakresem $\mathrm{pH}$ i w niższej oraz wyższej temperaturze;

- Spritase HiTaA 27105L - płynny enzym stworzony w celu upłynniania skrobi do rozpuszczalnych dekstryn i oligosacharydów. Jest mikrobiologiczną termostabilną $\alpha$-amylazą pochodzącą ze szczepu Bacillus licheniformis. Korzyścią zastosowania tego produktu jest upłynnianie skrobi w wysokiej temperaturze, z zakresu $85 \div 110^{\circ} \mathrm{C}$ (optymalnie $90 \div 95^{\circ} \mathrm{C}$ ). Optymalne $\mathrm{pH}$ wynosi $5,5 \div 6,5$, ale zakres $\mathrm{pH}$ jest szerszy: $5,0 \div 8,5$.

Do hydrolizy celulozy zastosowano:

- Biotouch C800 - enzym produkowany biosyntetycznie przy udziale genetycznie modyfikowanego szczepu Trichoderma reesei, wykazuje działanie na wiązania endo-1,4-beta-D-glikozydowe w cząsteczkach celulozy. Zawiera izolowane endoglukanazy (jeden z typów celulaz). Jest to ciemnobrązowy płyn o zakresie stosowania pH $5,0 \div 6,5 \mathrm{i}$ w temperaturze $50 \div 65^{\circ} \mathrm{C}$. To enzym ulegający całkowitej biodegradacji i bezpieczny dla środowiska. Pozostałe środki chemiczne, które brano pod uwagę jako dodatki do cieczy zabiegowej, to środki oznakowane w następujący sposób:

- A - środek zapobiegający pęcznieniu minerałów ilastych;

- B - środek przeciwemulgujący, redukujący napięcie powierzchniowe; 
- C - micelarny środek powierzchniowo czynny, służący do usprawnienia procesu odzyskiwania cieczy pozabiegowej. Redukuje napięcie powierzchniowe i ciśnienie kapilarne, co pomaga przy przepływie przez ośrodek porowaty lub szczeliny. Poprawia przepuszczalność względną skał zbiornikowych dla cieczy poreakcyjnej;

- D - środek powodujący zmniejszenie oporów przepływu. Poprawia penetrację cieczy zabiegowej w skale zło- żowej, usprawnia proces usuwania cieczy pozabiegowej i oczyszczanie odwiertu.

Do usunięcia uszkodzenia spowodowanego płuczką wiertniczą zaproponowano dwuetapową metodę stymulacji. Pierwszy etap polegał na usunięciu osadów iłowych z placka filtracyjnego poprzez rozkład skrobi i celulozy za pomocą enzymów, a drugi etap na usunięciu blokatora węglanowego za pomocą kwasowania.

\section{Badania kompatybilności i pH roztworów enzymów}

Założono, że nośnikiem enzymów do odwiertu będzie woda lub 2-proc. roztwór $\mathrm{KCl}$. Do nich dodawano środki chemiczne, których rolą było ograniczenie pęcznienia minerałów ilastych, a także: zmniejszenie oporów przepływu, lepsza penetracja cieczy zabiegowej w skałę złożową, usprawnienie procesu usuwania cieczy pozabiegowej i oczyszczanie odwiertu. Ponieważ interakcje pomiędzy enzymami a dodatkami do cieczy zabiegowej nie są znane, wykonano testy kompatybilności oraz zmierzono $\mathrm{pH}$ zarówno cieczy na bazie $2 \% \mathrm{KCl}$, jak i wody. Przykładowe wyniki badań pH podano w tablicy 1 .

Badania kompatybilności wykonano zarówno dla czystych roztworów enzymów, jak i cieczy wymywających składających się z enzymów i pozostałych dodatków chemicznych.

Wszystkie środki chemiczne dobrze mieszały się z solanką i z wodą. Podczas mieszania ich ze sobą w temperaturze pokojowej nie powstawały żadne produkty uboczne, natomiast podczas podgrzewania do wyższej temperatury w niektórych roztworach zachodziły zmiany: zmiana barwy roztworu lub wytrącenie się białego osadu. Przykład pokazano na fotografii 1.

W tablicy 2 zamieszczono wyniki testów kompatybilności płynów czyszczących w różnych kombinacjach stężeń enzymów oraz pozostałych dodatków chemicznych.

Wykonane badania cieczy czyszczących na bazie enzymów pokazały, w jaki sposób należy je przygotowywać oraz z jakimi dodatkami chemicznymi można je łączyć. W tablicy 2 oznaczono jako „,+” płyn kompatybilny, natomiast jako ,,-" płyn, w którym wystąpiła jakakolwiek zmiana.

$\mathrm{Z}$ badań tych wysuwają się następujące wnioski: połączone enzymy Tegamyl HL120L $(0,30 \mathrm{ml} / \mathrm{l})+$ Biotouch C800 (1\%) ze środkiem C powodują w temperaturze powyżej $60^{\circ} \mathrm{C}$ wytrącanie się części stałych. Przed dalszymi badaniami odrzucono wszystkie ciecze, w których w temp. $60^{\circ} \mathrm{C}$ i wyższej następowało wytrącanie się cząstek stałych.
Tablica 1. Wartości pH wodnych roztworów enzymów

\begin{tabular}{|l|c|c|}
\hline $\begin{array}{l}\text { Ciecz wymywająca na bazie wody } \\
\text { wodociągowej, koncentracja }\end{array}$ & $\mathrm{pH}$ & $\begin{array}{c}\text { Temperatura } \\
{\left[{ }^{\circ} \mathrm{C}\right]}\end{array}$ \\
\hline Woda & 7,44 & 22,2 \\
\hline $\begin{array}{l}\text { Tegamyl HL120L } \\
0,14 \mathrm{ml} / 1\end{array}$ & 7,54 & 22,8 \\
\hline $\begin{array}{l}\text { Tegamyl HL120L } \\
0,20 \mathrm{ml} / 1\end{array}$ & 7,54 & 24,4 \\
\hline $\begin{array}{l}\text { Tegamyl HL120L } \\
0,30 \mathrm{ml} / 1\end{array}$ & 7,50 & 24,8 \\
\hline $\begin{array}{l}\alpha \text {-amylaza } \\
0,14 \mathrm{ml} / 1\end{array}$ & 7,75 & 23,7 \\
\hline $\begin{array}{l}\alpha \text {-amylaza } \\
0,20 \mathrm{ml} / 1\end{array}$ & 7,65 & 23,8 \\
\hline $\begin{array}{l}\alpha \text {-amylaza } \\
0,30 \mathrm{ml} / 1\end{array}$ & 7,65 & 23,3 \\
\hline
\end{tabular}

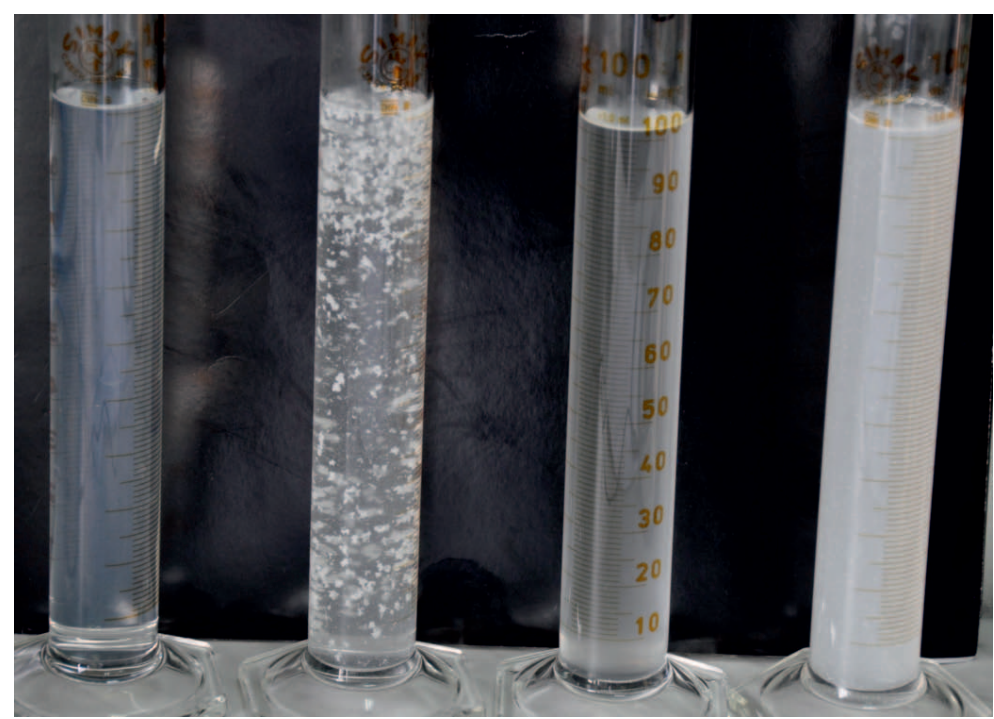

Fot. 1. Wygląd mieszaniny po ogrzaniu do temp. $60^{\circ} \mathrm{C}$, od lewej strony:

A) woda wodociągowa + Tegamyl HL120L $(0,3 \mathrm{ml} / \mathrm{l})+\mathrm{A}(0,2 \%)+\mathrm{C}(0,2 \%)$;

B) woda wodociągowa + Tegamyl HL120L $(0,3 \mathrm{ml} / \mathrm{l})+\mathrm{A}(0,2 \%)+\mathrm{B}(1 \%)$;

C) woda wodociągowa $+\alpha$-amylaza $(0,3 \mathrm{ml} / 1)+\mathrm{A}(0,2 \%)+\mathrm{C}(0,2 \%)$;

D) woda wodociągowa $+\alpha$-amylaza $(0,3 \mathrm{ml} / \mathrm{l})+\mathrm{A}(0,2 \%)+\mathrm{B}(1 \%)$ 
Tablica 2. Zestawienie wyników badań kompatybilności

\begin{tabular}{|c|c|c|c|c|c|c|c|c|c|c|}
\hline \multirow{2}{*}{ Enzym } & \multirow{2}{*}{ Rodzaj cieczy } & \multicolumn{9}{|c|}{ Temperatura $\left[{ }^{\circ} \mathrm{C}\right]$} \\
\hline & & pok. & 30 & 40 & 50 & 60 & 70 & 75 & 80 & 85 \\
\hline \multirow{8}{*}{$\begin{array}{l}\text { Tegamyl } \\
\text { HL120L }\end{array}$} & $2 \% \mathrm{KCl}+2 \% \mathrm{D}+0,14 \mathrm{ml} / 1$ Tegamyl HL120L & + & + & - & - & - & & & & \\
\hline & $2 \% \mathrm{KCl}+2 \% \mathrm{D}+0,3 \mathrm{ml} / 1$ Tegamyl HL120L & + & + & - & - & - & & & & \\
\hline & Woda $+2 \% \mathrm{D}+0,3 \mathrm{ml} / 1$ Tegamyl HL120L & + & + & + & + & - & & - & & \\
\hline & $2 \% \mathrm{KCl}+0,3 \mathrm{ml} / 1$ Tegamyl HL120L & + & + & + & + & + & & + & & \\
\hline & Woda $+0,3 \mathrm{ml} / 1$ Tegamyl HL120L & + & + & + & + & + & & + & & \\
\hline & Woda $+0,2 \% \mathrm{~A}+0,3 \mathrm{ml} / 1$ Tegamyl HL120L & + & + & + & + & + & & + & & \\
\hline & Woda $+0,2 \% \mathrm{~A}+0,3 \mathrm{ml} / 1$ Tegamyl HL120L $+0,2 \% \mathrm{C}$ & + & + & + & + & + & + & - & - & \\
\hline & Woda $+0,2 \% \mathrm{~A}+0,3 \mathrm{ml} / 1$ Tegamyl HL120L $+1 \% \mathrm{~B}$ & - & - & - & - & - & - & - & - & \\
\hline \multirow{7}{*}{$\alpha$-amylaza } & $2 \% \mathrm{KCl}+2 \% \mathrm{D}+0,3 \mathrm{ml} / 1 \alpha$-amylaza & + & + & + & - & - & & - & & \\
\hline & Woda $+2 \% \mathrm{D}+0,3 \mathrm{ml} / 1 \alpha$-amylaza & + & + & + & + & + & - & & & \\
\hline & $2 \% \mathrm{KCl}+0,3 \mathrm{ml} / 1 \alpha$-amylaza & + & + & + & + & - & - & - & & \\
\hline & Woda $+0,3 \mathrm{ml} / 1 \alpha$-amylaza & + & + & + & + & + & + & + & & \\
\hline & Woda $+0,2 \% \mathrm{~A}+0,3 \mathrm{ml} / 1 \alpha$-amylaza & + & + & + & + & + & + & + & & \\
\hline & Woda $+0,2 \% \mathrm{~A}+0,30 \mathrm{ml} / 1 \alpha$-amylaza $+0,2 \% \mathrm{C}$ & + & + & + & + & + & + & - & - & \\
\hline & Woda $+0,2 \% \mathrm{~A}+0,30 \mathrm{ml} / 1 \alpha$-amylaza $+1 \% \mathrm{~B}$ & - & - & - & - & - & - & - & - & \\
\hline \multirow{7}{*}{$\begin{array}{c}\text { Tegamyl } \\
\text { HL120L, } \\
\alpha \text {-amylaza, } \\
\text { Spritase HiTaA } \\
\text { 27105L, } \\
\text { Biotouch C } 800\end{array}$} & Woda $+0,2 \% \mathrm{~A}+0,3 \mathrm{ml} / 1$ Tegamyl HL120L + 1\% Biotouch C800 & + & + & + & + & + & + & + & + & \\
\hline & Woda $+0,2 \% \mathrm{~A}+0,30 \% \alpha$-amylaza $+1 \%$ Biotouch C 800 & + & + & + & + & + & + & + & + & \\
\hline & Woda $+0,2 \% \mathrm{~A}+0,3 \%$ Tegamyl HL120L $+1 \%$ Biotouch C $800+0,2 \% \mathrm{C}$ & + & + & + & + & + & - & & & \\
\hline & Woda $+0,2 \% \mathrm{~A}+0,30 \mathrm{ml} / 1 \alpha$-amylaza $+1 \%$ Biotouch $\mathrm{C} 800+0,2 \% \mathrm{C}$ & + & + & + & + & + & - & & & \\
\hline & Woda $+0,2 \% \mathrm{~A}+1 \%$ Tegamyl HL120L $+1 \%$ Biotouch C800 & + & + & + & + & + & + & $+/-$ & - & \\
\hline & Woda $+0,2 \% \mathrm{~A}+1 \% \alpha$-amylaza $+1 \%$ Biotouch C 800 & + & + & + & + & + & + & + & + & + \\
\hline & Woda $+0,2 \% \mathrm{~A}+1 \%$ Spritase HiTaA $27105 \mathrm{~L}+1 \%$ Biotouch C 800 & + & + & + & + & + & + & + & + & \\
\hline
\end{tabular}

\section{Badanie jakości wymywania osadu z płuczki wiertniczej za pomocą roztworów enzymów}

Badania te polegały na kapilarnym zasysaniu płuczki przez 60 minut przez wysuszoną kostkę z piaskowca. Zasysanie odbywało się w łaźni w temperaturze $60^{\circ} \mathrm{C}$. Następnie na specjalnie przygotowanym stanowisku, za pomocą mieszadła mechanicznego przy $1000 \mathrm{obr}$./min, prowadzono wymywanie wytworzonych osadów. Jakość wymywania oceniano na podstawie obserwacji czasu, po którym następowało całkowite usunięcie osadu.

Tablica 3. Czas wymywania osadu z płuczki beziłowej z blokatorami roztworem Tegamyl HL120L

\begin{tabular}{|l|c|c|}
\hline $\begin{array}{c}\text { Ciecz wymywająca na } \\
\text { bazie wody wodociągowej, } \\
\text { koncentracja }\end{array}$ & $\begin{array}{c}\text { Temperatura } \\
\text { testu wymywania } \\
{\left[{ }^{\circ} \mathrm{C}\right]}\end{array}$ & $\begin{array}{c}\text { Czas } \\
\text { wymywania } \\
{[\mathrm{min}]}\end{array}$ \\
\hline Woda & 60 & 33 \\
\hline $\begin{array}{l}\text { Tegamyl HL120L } \\
0,14 \mathrm{ml} / 1\end{array}$ & 60 & 12 \\
\hline $\begin{array}{l}\text { Tegamyl HL120L } \\
0,20 \mathrm{ml} / 1\end{array}$ & 60 & 8 \\
\hline $\begin{array}{l}\text { Tegamyl HL120L } \\
0,30 \mathrm{ml} / 1\end{array}$ & 60 & 5 \\
\hline
\end{tabular}

W tablicach 3 i 4 pokazano przykładowe wyniki badań czasu wymywania osadu wodnymi roztworami enzymów w zależności od ich stężenia.

Podejmowano także próby obniżenia pH płynów czyszczących za pomocą kwasu cytrynowego. Sprawdzano czas wymywania przez płyny czyszczące bez zmienionego $\mathrm{pH}$ i z obniżonym $\mathrm{pH}$ roztworu wymywającego. Jak można zauważyć w tablicy 5 , czas wymywania skraca się.

Tablica 4. Czas wymywania osadu z płuczki beziłowej z blokatorami wodnym roztworem $\alpha$-amylazy

\begin{tabular}{|l|c|c|}
\hline $\begin{array}{c}\text { Ciecz wymywająca na ba- } \\
\text { zie wody wodociągowej, } \\
\text { koncentracja }\end{array}$ & $\begin{array}{c}\text { Temperatura te- } \\
\text { stu wymywania } \\
{\left[{ }^{\circ} \mathrm{C}\right]}\end{array}$ & $\begin{array}{c}\text { Czas wymy- } \\
\text { wania } \\
{[\mathrm{min}]}\end{array}$ \\
\hline Woda & 60 & 33 \\
\hline $\begin{array}{l}\alpha \text {-amylaza } \\
0,14 \mathrm{ml} / 1\end{array}$ & 60 & 13 \\
\hline $\begin{array}{l}\alpha \text {-amylaza } \\
0,20 \mathrm{ml} / 1\end{array}$ & 60 & 10 \\
\hline $\begin{array}{l}\alpha \text {-amylaza } \\
0,30 \mathrm{ml} / 1\end{array}$ & 60 & 6 \\
\hline
\end{tabular}


Tablica 5. Zestawienie czasu wymywania na dyskach przez płyny czyszczące dla płynów na bazie wody bez zmienionego $\mathrm{pH}$ i z obniżonym $\mathrm{pH}$

\begin{tabular}{|l|c|c|c|c|c|}
\hline \multicolumn{1}{|c|}{ Roztwory } & $\begin{array}{c}\text { Temperatura } \\
{\left[{ }^{\circ} \mathrm{C}\right]}\end{array}$ & $\mathrm{pH}$ & $\begin{array}{c}\text { Czas usunięcia } \\
\text { osadu } \\
{[\mathrm{s}]}\end{array}$ & $\begin{array}{c}\mathrm{pH} \\
\mathrm{pH} \\
\text { osadu } \\
{[\mathrm{s}]}\end{array}$ \\
\hline Woda $+\mathrm{A}(0,2 \%)+$ Tegamyl HL120L $(1 \%)+$ Biotouch C800 $(1 \%)$ & 22,5 & 6,87 & 30 & 5,73 & 20 \\
\hline Woda + A $(0,2 \%)+\alpha$-amylaza $(1 \%)+$ Biotouch C800 $(1 \%)$ & 23,0 & 6,92 & 35 & 5,86 & 23 \\
\hline Woda + A $(0,2 \%)+$ Spritase HiTaA $27105 \mathrm{~L}(1 \%)+$ Biotouch C800 $(1 \%)$ & 22,6 & 6,96 & 38 & 5,62 & 28 \\
\hline
\end{tabular}

\section{Badania reologiczne}

Płuczka odtworzona w laboratorium miała $\mathrm{pH}$ powyżej 9. W związku z tym zwiększono stężenia enzymów w cieczach czyszczących. W odwiercie skrobia i celuloza są obecne w placku filtracyjnym w ilościach, które jest bardzo trudno określić, trudno także oceniać, jakie jest pH. Dlatego założono, że będzie ono zbliżone do pH płuczki. By sprawdzić stopień rozkładu celulozy i skrobi spowodowany enzymami, przeprowadzono badania reologiczne, wprowadzając składniki płynu czyszczącego do płuczki. Badania wykonano dla płynów czyszczących o składzie:

- $1 \%$ Tegamyl HL120L + 0,2\% A + 1\% Biotouch C800,

- $1 \% \alpha$-amylaza $+0,2 \% \mathrm{~A}+1 \%$ Biotouch C800,

- $1 \%$ Spritase HiTaA $27105 \mathrm{~L}+$ $0,2 \% \mathrm{~A}+1 \%$ Biotouch C 800 .

Dla porównania wykonano badania reologiczne płuczki beziłowej bez enzymów i pozostałych dodatków chemicznych. Badania prowadzono w temperaturze pokojowej i w temperaturze $60^{\circ} \mathrm{C}$.

Badania pokazały, że wszystkie zestawy enzymów w ciągu $15 \div 20$ minut działania w temperaturze $60^{\circ} \mathrm{C}$ obniżają lepkość płuczki od $75 \%$ do ponad $80 \%$. Przykładowe wyniki badań pokazano w tablicach 6, 7 i 8.

Wszystkie ciecze z enzymami charakteryzowały się niemal identycznym działaniem na lepkość płuczki w temperaturze badania. Do dalszych testów wybrano jedną z nich, mianowicie ciecz o składzie: woda $+0,2 \% \mathrm{~A}+1 \%$ Tegamyl HL120L $+1 \%$ Biotouch C800.
Tablica 6. Badania reologiczne płuczki beziłowej

\begin{tabular}{|c|c|c|}
\hline $\begin{array}{c}\text { Obroty } \\
\text { wiskozymetru } \\
{[\mathrm{RPM}]}\end{array}$ & $\begin{array}{c}\text { Odczyt } \\
\text { wiskozymetru }[\mathrm{deg}] \\
\text { temperatura } 23^{\circ} \mathrm{C}\end{array}$ & $\begin{array}{c}\text { Odczyt } \\
\text { wiskozymetru }[\mathrm{deg}] \\
\text { temperatura } 60^{\circ} \mathrm{C}\end{array}$ \\
\hline 600 & 235 & 90 \\
\hline 300 & 140 & 54 \\
\hline 200 & 110 & 41 \\
\hline 100 & 69 & 25 \\
\hline 6 & 10 & 4 \\
\hline 3 & 6 & 2 \\
\hline
\end{tabular}

Tablica 7. Badania reologiczne: płuczka $+0,2 \% \mathrm{~A}+1 \%$ Tegamyl HL120L + $1 \%$ Biotouch $\mathrm{C} 800$, temperatura $23^{\circ} \mathrm{C}$

\begin{tabular}{|c|c|c|c|c|}
\hline $\begin{array}{c}\text { Obroty } \\
\text { wiskozymetru } \\
{[\text { RPM] }}\end{array}$ & $\begin{array}{c}\text { Odczyt } \\
\text { wiskozymetru } \\
{[\mathrm{deg}]} \\
\text { po } 5 \text { min }\end{array}$ & $\begin{array}{c}\text { Odczyt } \\
\text { wiskozymetru } \\
{[\mathrm{deg}]} \\
\text { po } 10 \mathrm{~min}\end{array}$ & $\begin{array}{c}\text { Odczyt } \\
\text { wiskozymetru } \\
{[\mathrm{deg}]} \\
\text { po } 15 \text { min }\end{array}$ & $\begin{array}{c}\text { Odczyt } \\
\text { wiskozymetru } \\
{[\mathrm{deg}]} \\
\text { po 20 min }\end{array}$ \\
\hline 600 & 69 & 55 & 52 & 52 \\
\hline 300 & 38 & 30 & 29 & 29 \\
\hline 200 & 26 & 22 & 21 & 21 \\
\hline 100 & 16 & 13 & 13 & 13 \\
\hline 6 & 3 & 2 & 2 & 1 \\
\hline 3 & 1 & 1 & 1 & 2 \\
\hline
\end{tabular}

Tablica 8. Badania reologiczne: płuczka $+0,2 \% \mathrm{~A}+1 \%$ Tegamyl HL120L + $1 \%$ Biotouch C 800 , temperatura $60^{\circ} \mathrm{C}$

\begin{tabular}{|c|c|c|c|c|}
\hline $\begin{array}{c}\text { Obroty } \\
\text { wiskozymetru } \\
{[\text { RPM] }}\end{array}$ & $\begin{array}{c}\text { Odczyt } \\
\text { wiskozymetru } \\
{[\mathrm{deg}]} \\
\text { po } 5 \text { min }\end{array}$ & $\begin{array}{c}\text { Odczyt } \\
\text { wiskozymetru } \\
{[\mathrm{deg}]} \\
\text { po } 10 \text { min }\end{array}$ & $\begin{array}{c}\text { Odczyt } \\
\text { wiskozymetru } \\
{[\mathrm{deg}]} \\
\text { po } 15 \text { min }\end{array}$ & $\begin{array}{c}\text { Odczyt } \\
\text { wiskozymetru } \\
{[\mathrm{deg}]} \\
\text { po 20 min }\end{array}$ \\
\hline 600 & 35 & 34 & 32 & 32 \\
\hline 300 & 20 & 19 & 17 & 17 \\
\hline 200 & 15 & 14 & 12 & 12 \\
\hline 100 & 10 & 9 & 7 & 7 \\
\hline 6 & 2 & 2 & 2 & 1 \\
\hline 3 & 1 & 1 & 1 & 2 \\
\hline
\end{tabular}




\section{Badania przepływowe na rdzeniach naturalnych}

Następnym krokiem były badania skuteczności usuwania placka filtracyjnego (w temperaturze $60^{\circ} \mathrm{C}$ ) utworzonego przez płuczkę na rdzeniach pochodzących z odwiertu $\mathrm{S}$ o średnicy 1,5" i długości około 1". Do badań tych wykorzystano prasę hydrauliczną i komorę do badań filtracji, przedstawione na fotografii 2.

W badaniach użyto płynu o składzie: woda $+0,2 \% \mathrm{~A}+$ 1\% Tegamyl HL120L + 1\% Biotouch C800.

Ponieważ założono, że proces usuwania uszkodzenia będzie przebiegał dwuetapowo, po przemywaniu roztworem enzymów, a przed kwasowaniem zastosowano bufor z 5-proc. roztworu $\mathrm{NH}_{4} \mathrm{Cl}$.

Założono, że parametrem kontrolującym efektywność usuwania uszkodzenia spowodowanego przez placek filtracyjny i filtrat będzie współczynnik przepuszczalności rdzenia.

Usuwanie uszkodzenia za pomocą roztworu enzymów odbywało się poprzez przepływ po powierzchni rdzenia z jednoczesną filtracją przez rdzeń, z przeciwciśnieniem równym $800 \mathrm{psi}$, z wydatkiem $30 \mathrm{ml} / \mathrm{min}$. Na rysunku 1 pokazano rezultaty badań przepływowych dla rdzenia, którego współczynnik przepuszczalności wynosił 33,5 mD.

I etap badania to uszkadzanie rdzenia odtworzoną płuczką. W tym przypadku uszkodzenie płuczką wiertniczą wynosiło prawie $55,5 \%$.

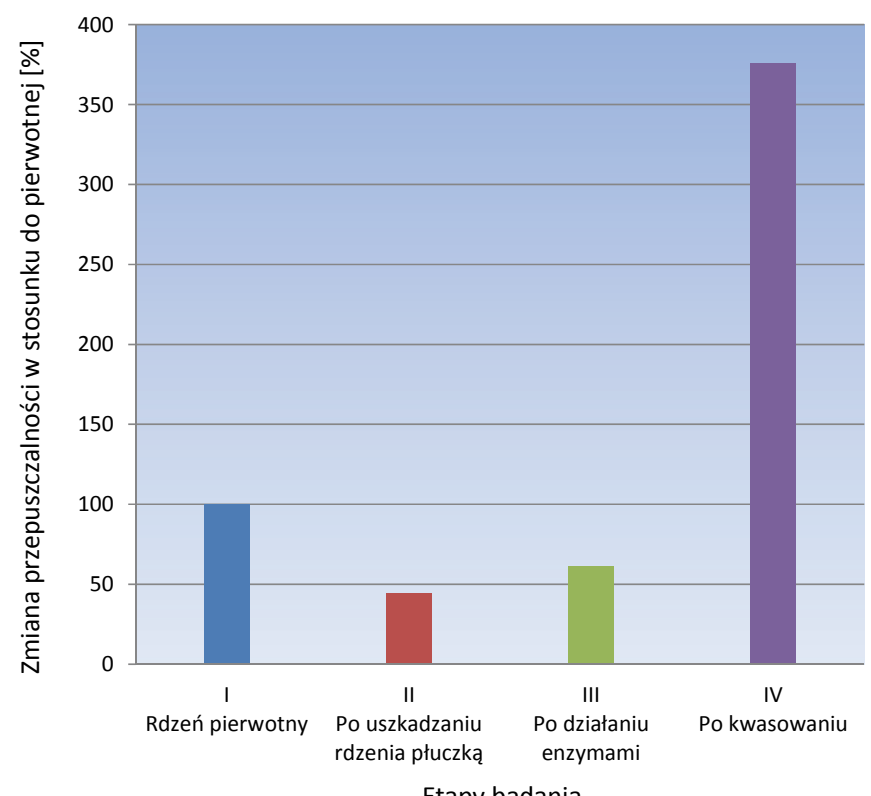

Rys. 1. Zmiana przepuszczalności po kolejnych etapach badania, wyrażona w procentach
II etap to płukanie roztworem enzymów. Przepuszczalność rdzenia poprawiła się i uszkodzenie wyniosło $38,91 \%$. Jak widać, płukanie roztworem enzymów poprawia przepuszczalność rdzenia, ale nie usuwa węglanów z placka filtracyjnego.

III etap to przemycie 5-proc. $\mathrm{NH}_{4} \mathrm{Cl}$, a następnie kwasowanie. $\mathrm{W}$ pierwszej kolejności 10-proc. $\mathrm{HCl}$ z dodatkami, a następnie mieszaniną 6,5-proc. $\mathrm{HCl}$ i 1-proc. $\mathrm{HF}$, również $\mathrm{z}$ dodatkami. Po tym teście przepuszczalność rdzenia wzrosła ponad trzykrotnie.

Kolejny przykład badania pokazano na rysunku 2. Intencją tego badania było sprawdzenie skuteczności przyjętej metody na rdzeniu o najniższej przepuszczalności pierwotnej. Badanie wykonano na rdzeniu o przepuszczalności $1,30 \mathrm{mD}$. Zastosowano te same enzymy $i$ te same kwasy.

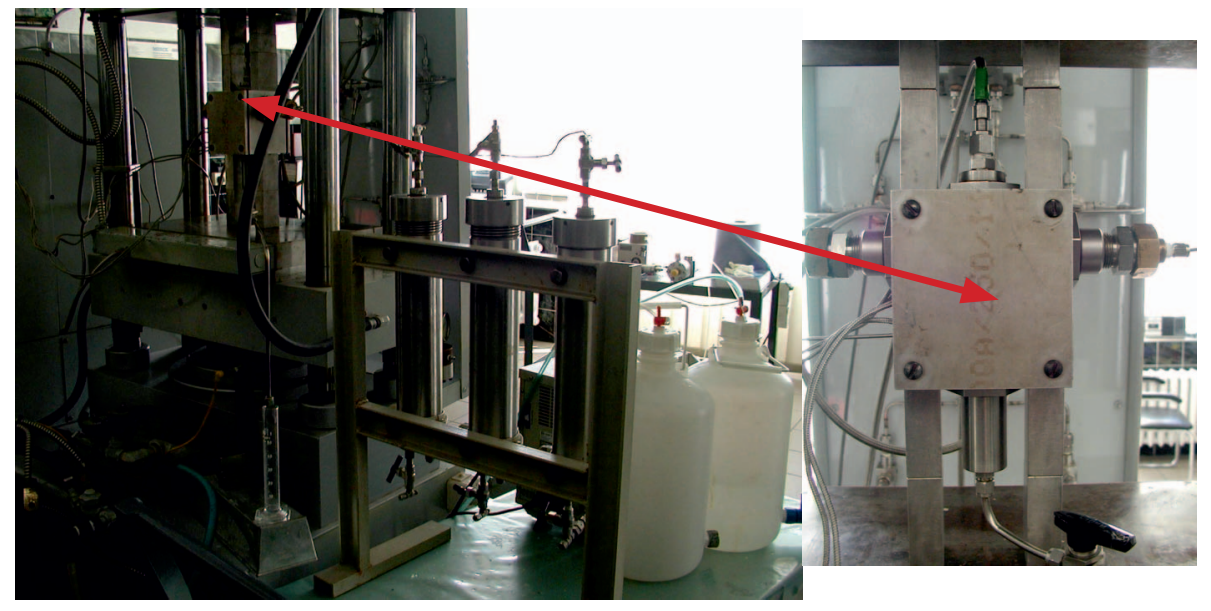

Fot. 2. Stanowisko do pomiaru filtracji na prasie hydraulicznej wraz z komorą filtracyjną

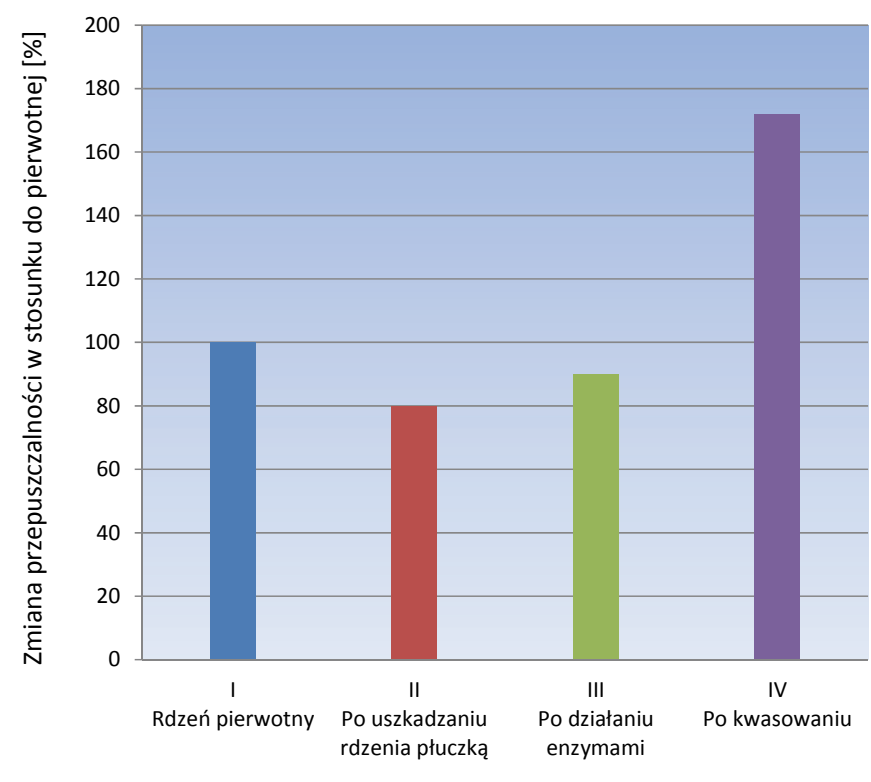

Etapy badania

Rys. 2. Zmiana przepuszczalności po kolejnych etapach badania, wyrażona w procentach 
W tym przypadku uszkodzenie płuczką wiertniczą wyniosło $20 \%$. Po usuwaniu tego uszkodzenia roztworem enzymów uszkodzenie zmalało do $10 \%$. Zastosowanie kwa- sów do usunięcia blokatorów węglanowych z placka filtracyjnego spowodowało wzrost przepuszczalności rdzenia o $70 \%$.

\section{Podsumowanie}

Celem pracy było sprawdzenie możliwości wykorzystania enzymów do usuwania uszkodzenia strefy przyodwiertowej spowodowanego przez składniki płuczki wiertniczej stosowanej przy dowiercaniu.

Wykonane badania roztworów enzymów i cieczy czyszczących na bazie enzymów pokazały, w jaki sposób należy je przygotowywać oraz z jakimi dodatkami chemicznymi można je łączyć. Na podstawie badań wytypowano zestawy enzymów do zastosowania w temperaturze do $60^{\circ} \mathrm{C}$. Badania laboratoryjne potwierdziły skuteczność enzymów w procesie upłynniania placka filtracyjnego poprzez obniżenie jego lepkości. Wytypowane zestawy enzymów w ciągu $15 \div 20$ minut działania w temperaturze $60^{\circ} \mathrm{C}$ obniżały lepkość płuczki od $75 \%$ do ponad $80 \%$. Również badania przepływowe wykonane na rdzeniach potwierdziły tezę, że płyny na bazie enzymów zmniejszają lepkość pozostałości płuczki wiertniczej na ścianie odwiertu, rozpulchniając placek filtracyjny i w ten sposób zwiększając efektywność procesu oczyszczania. Jednak usunięcie blokatorów węglanowych z placka filtracyjnego nie jest możliwe bez kwasowania. Badania na rdzeniach pokazały, że kwasowanie matrycowe oprócz usunięcia blokatorów węglanowych spowodowało znaczny wzrost przepuszczalności skały złożowej - w jednym przypadku prawie dwukrotny, w drugim ponad trzykrotny.

Prosimy cytować jako: Nafta-Gaz 2016, nr 11, s. 926-933, DOI: 10.18668/NG.2016.11.05

Artykuł nadesłano do Redakcji 18.10.2016 r. Zatwierdzono do druku 9.11.2016 r.

Artykuł powstał na podstawie pracy badawczej pt. Technologia udrażniania złożowej strefy przyodwiertowej po dowiercaniu usuwanie filtratu i osadów filtracyjnych - praca INiG - PIB na zlecenie PGNiG S.A.; nr zlecenia 757/KS/2013, nr archiwalny DK-4100-97/13.

\section{Literatura}

[1] Beall B. B., Brannon H. D., Tjon Joe Pin R. M., O’Driscoll K.: Evaluation of a New Technique For Removing Horizontal Wellbore Damage Attributable to Grill-In Filter Cake. BJ Services Company, SPE 36429, 1996, s. 1-13.

[2] Błaż S.: Zapobieganie zanikom płuczek $w$ formacje skalne w procesie wiercenia. Nafta-Gaz 2011, nr 3, s. 182-191.

[3] Cleansorb Ltd.; http://www.cleansorb.com (dostęp: 16.03.2013).

[4] Economides M.J., Nolte K.G. (eds.): Reservoir Stimulation. Third edition. WILEY, Houston, TX, 2000, chapter 7.

[5] French Ch. E.: Synthetic biology and biomass conversion: a match made in heaven. J. R. Soc. Interface 2009; https:// www.ncbi.nlm.nih.gov/pubmed/19454530 (dostęp: 2.09.2016).

[6] Luyster M. R., Monroe T. D., Ali S. A.: Factors Affecting the Performance of Enzyme Breakers for Removal of Xanthan-Based Filter Cakes. Chevron Petroleum Technology Company, SPE 58749, 2000, s. 1-14.

[7] Nasr-El-Din H. A., Al-Otaibi M. B., Al-Qahtani A. A., Al-Fuwaires O. A.: Filter-Cake Cleanup in MRC Wells Using Enzyme/Surfactant Solutions. SPE 98300, 2006, s. 1-14.

[8] Nasr-El-Din H. A., Al-Otaibi M. B., Al-Qahtani A. A., Samuel M. M.: An Effective Fluid Formulation to Remove Drilling-Fluid Mud Cake in Horizontal and Multi-Lateral Wells. SPE 87960-PA-P, 2007, s. 1-7.

[9] Pudło J., Dudek A.: Płuczki wiertnicze stosowane przez PSPW do wierceń i dowiercania złóż. Polski Serwis Płynów Wiertniczych, Krosno, s. 1-5; www.nbuv.gov.ua/old jrn/natural/ pnp/2007_5/book_n_5/ROZ/R_29.pdf(dostęp: 20.03.2013).

[10] Pudło J., Dudek A.: Technologie płuczkowe stosowane przez
PSPW Krosno. Konferencja Geopetrol - Zakopane, 2000, s. 489.

[11] Raczkowski J., Półchłopek T.: Materiały i środki chemiczne do sporzadzania płuczek wiertniczych. Prace Instytutu Górnictwa Naftowego i Gazownictwa nr 95, Kraków 1998.

[12] Sanders M. W., Twycross J., Buchan C. R., Cameron J. J.: A Quantitative Method for Estimating alfa-Amylase-Based Enzyme Concentrations in Wellsite Field Samples and its Application on a Gravel Pack Completion. SPE AADE-04DF-HO-35, 2004, s. 1-10.

[13] Uliasz M. i zespół: Badania laboratoryjne doboru rodzaju i własności płuczek wiertniczych do wiercenia otworów poziomych. Dokumentacja Instytutu Nafty i Gazu, Kraków, listopad 2005.

[14] Wysocki S., Bielewicz D., Wysocka W.: Badania wpływu nowo opracowanych pluczek kationowo-skrobiowych na zmianę przepuszczalności ośrodka przy użyciu filtrów ceramicznych. Wiertnictwo, Nafta, Gaz 2007, t. 24, z. 1, s. 627-632.

[15] Zima G.: Rozkład koloidów ochronnych pluczek wiertniczych środkami enzymatycznymi. Nafta-Gaz 2011, nr 4, s. 249-253.

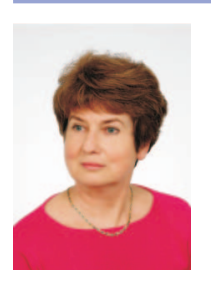

Mgr inż. Elżbieta BIAŁY

Starszy specjalista badawczo-techniczny w Zakładzie Stymulacji Wydobycia Węglowodorów. Instytut Nafty i Gazu - Państwowy Instytut Badawczy ul. Lubicz 25 A

31-503 Kraków

E-mail: elzbieta.bialy@inig.pl 